PEPATUDZU: Media Pendidikan dan Sosial Kemasyarakatan p-ISSN: 2087-3476 | e-ISSN: 2541-5700

\title{
PENGARUH MODEL KEPALA BERNOMOR STRUKTUR TERINTEGRASI NILAI-NILAI KEISLAMAN TERHADAP KEMAMPUAN PEMAHAMAN KONSEP MATEMATIS SISWA
}

\author{
Febryanti', Herlina Ahmad ${ }^{2}$ \\ Prodi Pendidikan Matematika Universitas Al Asyariah Mandar \\ e-mail: febryanti.lawa@gmail.com
}

\begin{abstract}
This study aims to determine the effect of the head numbered learning structure model on the material relations and integrated functions of Islamic values on the ability of students to understand mathematical concepts. This research was conducted at the Mega Link Majene Vocational School in class X with a total of 20 students. The research design used is the One Group Pretest Posttest design. The instrument of this research is the concept understanding ability test, observation sheet of student activity and observation sheet of the researcher in the learning process. The results showed that the average pretest score was 50,65 and the average post-test was 82,45 while the normalized $N$-gain calculation obtained an average increase in student learning outcomes was 0,60 (medium category) and the results of the t-test analysis were obtained. 4,21 with a significance value of $0,000<\alpha$. So it can be concluded that the application of the head learning model with integrated structure with Islamic values can affect the ability to understand students' mathematical concepts.
\end{abstract}

Keywords: head model numbered structure, relations and functions, islamic values, the ability to understand concepts

\section{PENDAHULUAN}

Revisi kurikulum 2013 yang tertuang dalam permendikbud nomor 24 tahun 2016 yang lampirannya menyatakan bahwa tujuan kurikulum tingkat SMA/SMK/MA sederajat mencakup empat kompetensi inti, yaitu (1) kompetensi sikap spritual, (2) sikap sosial, (3) pengetahuan, (4) keterampilan. Untuk mencapai kompetensi inti 1 salah satu cara yang dapat diterapkan oleh seorang guru matematika yaitu mengintegrasikan nilai-nilai keislaman pada materi pembelajaran. Kompetensi inti 2 dapat menerapkan suatu model pembelajaran, salah satunya yaitu model kooperatif tipe kepala bernomor struktur. Sedangkan kompetensi inti 3 dan 4 dapat dicapai dengan kreativitas guru dalam menyampaikan materi.

Data ujian nasional mata pelajaran matematika 3 tahun terakhir di SMK Mega Link Majene dengan nilai rata-rata matematika tahun ajaran 2015/2016 
adalah $61,62,2016 / 2017$ adalah 71,20 dan $2017 / 2018$ adalah 55,7 maka nilai ratarata ujian matematika 3 tahun terakhir 62,83 . Hal ini menunjukkan bahwa tingkat pemahaman konsep matematika yang dimiliki oleh siswa masih kurang, olehnya itu dibutuhkan usaha kreativitas guru dalam meningkatkan pemahaman konsep matematika siswa. Pendapat Djajadisastra dalam (Isjoni, 2007) pembelajaran kooperatif pada dasarnya merupakan metode gotong royong yang disusun dalam suatu kelompok kecil pada waktu menerima pembelajaran dan menyelesaikan soal-soal ataupun tugas yang diberikan oleh guru, dengan demikian model kooperatif tipe kepala bernomor struktur dapat diterapkan oleh guru dalam meningkatkan pemahaman konsep matematika siswa.

Materi relasi dan fungsi yang terintegrasi nilai keislaman membutuhkan model pembelajaran dalam penyampainnya. Model pembelajaran kooperatif yang mengutamakan kerja sama dalam menyelesaikan tugas yang diberikan oleh guru. Konstruktivisme social Vygotsky dalam (Suprijono, 2013) menekankan bahwa pengetahuan dibangun dan dikonstruksikan secara mutual. Keterlibatan dengan orang lain membuka kesempatan bagi siswa mengevaluasi dan memperbaiki pemahaman. Pengalaman dalam konteks social memberikan mekanisme penting untuk perkembangan pemikiran siswa sehingga model pembelajaran yang digunakan pada penilitian ini adalah model pembelajaran kooperatif tipe kepala bernomor struktur.

Model Pembelajaran kepala bernomor struktur dapat mendorong siswa untuk meningkatkan semangat kerja sama, belajar jadi menyenangkan tanpa ada perasaan tertekan sehingga siswa lebih mudah menyerap konsep-konsep yang dipalajari dan lebih leluasa mengungkapkan hasil pemikirannya khususnya tugas kelompok yang diberikan oleh guru.

Adapun langkah-langkah model kepala bernomor struktur menurut (Nasional, D. P, 2010) yaitu:

1. Siswa dibagi dalam kelompok, setiap siswa dalam kelompok mendapat nomor.

2. Penugasan diberikan kepada setiap siswa berdasarkan nomor terhadap tugas yang berangkai. Misalnya nomor satu bertugas mencatat soal, siswa nomor dua mengerjakan soal dan siswa nomor tiga melaporkan hasil pekerjaan dan seterusnya.

3. Jika perlu, guru bisa menyuruh kerja sama antar kelompok. Siswa disuruh keluar dari kelompoknya dan bergabung bersama beberapa siswa bernomor sama dari kelompok lain. Dalam kesempatan ini siswa dengan tugas yang sama bisa saling membantu atau mencocokkan hasil kerja sama siswa.

4. Laporkan hasil dan tanggapan dari kelompok yang lain.

5. Kesimpulan. 
Penerapan nilai-nilai islam dalam proses pembelajaran dapat menimbulkan kesadaran pada siswa, ada tiga hal yang dapat disampaikan dalam proses pembelajaran yaitu aqidah, ibadah, akhlak. (Abdussakir, 2018) mengatakan bahwa integrasi matematika dan agama telah banyak didiskusikan. Fakta dilapangan menunjukkan bahwa masih banyak pendidik yang kesulitan menintegrasikan matematika dan agama. Praktik yang ditemukan di sekolah hanyalah ayat-ayat alquran dan hadist tetang topik-topik tertentu, karena belum adanya model standar untuk pelaksanaan matematika dan agama. Pendapat (Abdussakir, 2017) merumuskan empat model matematika dan alquran yaitu (1) matematika dari alquran, (2) matematika untuk alquran, (3) matematika ke alquran dan (4) matematika dengan alquran. Aspek nilai-nilai Islam menurut (Nasir M, 2017) dalam pembelajaran dibedakan menjadi 3 jenis, yaitu (1) nilainilai aqidah mengajarkan manusia untuk percaya akan adanya Allah Yang Maha Esa dan Maha Kuasa sebagai Sang Pencipta alam semesta, yang akan senantiasa mengawasi dan memperhitungkan segala perbuatan manusia di dunia. (2) nilainilai ibadah mengajarkan pada manusia agar dalam setiap perbuatannya senantiasa dilandasi hati yang ikhlas guna mencapai ridho Allah. Pengamalan konsep nilai-nilai ibadah akan melahirkan manusia-manusia yang adil, jujur, dan suka membantu sesamanya. (3) nilai akhlak mengajarkan kepada manusia untuk bersikap dan berperilaku yang baik sesuai norma atau adab yang benar dan baik, sehingga akan membawa pada kehidupan manusia yang tenteram, damai, harmonis, dan seimbang. Dengan demikian nilai-nilai ajaran Islam merupakan nilai-nilai yang akan mampu membawa manusia pada kebahagiaan, kesejahteraan, dan keselamatan manusia baik dalam kehidupan di dunia maupun di akhirat.

Salah satu tujuan penting dalam pembelajaran matematika adalah kemampuan pemahaman matematika siswa. Guru dalam memberikan materi pelajaran bukan hanya sebagai hafalan, namun lebih dari itu pemahaman siswa dapat lebih mengerti akan konsep materi pelajaran. Michener dalam (Arifin, N, 2014) menyatakan bahwa pemahaman merupakan salah satu aspek dalam Taksonomi Bloom. Pemahaman diartikan sebagai penyerapan arti suatu materi bahan yang dipelajari. Untuk memahami suatu objek secara mendalam seseorang harus mengetahui: (1) objek itu sendiri, (2) relasinya dengan objek lain yang sejenis, (3) relasinya dengan objek lain yang tidak sejenis, (4) relasi-dual dengan objek lainnya yang sejenis dan (5) relasi dengan objek dalam teori lainnya.

Pemahaman konsep merupakan salah satu kecakapan atau kemahiran matematika yang diharapkan dapat tercapai dalam belajar matematika yaitu dengan menunjukkan pemahaman konsep matematika yang dipelajarinya, menjelaskan keterkaitan antar konsep dan mengaplikasikan konsep atau Algoritma secara luwes, akurat, efisien dan tepat dalam pemecahan masalah (Kesumawati, 2008) dan Menurut (Herawati, 2010) Pemahaman konsep perlu 
ditanamkan kepada siswa sejak dini, karena siswa harus memahami tentang definisi, pengertian, cara pemecahan masalah maupun pengoperasian matematika secara benar. Kemampuan pemahaman konsep matematika merupakan salah satu bagian yang utama yang hendak dicapai dalam tujuan pembelajaran (Sari, 2018). Berdasarkan penjelasan tersebut maka pemahaman konsep merupakan kemampuan fundamental yang harus dimiliki oleh siswa karena dengan penguasaan konsep akan memudahkan siswa dalam menyelesaikan masalah matematika

Indikator kemampuan pemahaman siswa terhadap konsep matematika menurut (NCTM, 2000) yaitu:

1. Mengidentifikasi konsep secara verbal dan tulisan.

2. Membuat contoh dan non contoh penyangkalan.

3. Mempresentasikan suatu konsep dengan model, diagram dan symbol.

4. Mengubah suatu bentuk representasi ke bentuk lain.

5. Mengidentifikasi sifat-sifat suatu konsep dengan mengenal syarat-syarat yang menentukan suatu konsep.

6. Mengenal berbagai makna dan interprestasi konsep.

\section{METODE PENELITIAN}

Penelitian ini adalah penelitian eksperimen dengan desain eksperimen one grup pre-test post-test desain yang bertujuan untuk mengetahui pengaruh penerapan model pembelajaran kooperatif tipe kepala bernomor struktur pada materi relasi dan fungsi terintegrasi nilai keislaman terhadap kemampuan pemahaman konsep matematis siswa. penelitian eksperimen dapat diartikan sebagai metode penelitian yang digunakan untuk mencari pengaruh perlakuan tertentu terhadap yang lain dalam kondisi yang terkendalikan (Sugiono,2016). Subjek penelitian yaitu siswa kelas X SMK Mega Link Majene yang berjumlah 20 orang. Kegiatan pembelajaran dilakukan sebanyak 3 kali pertemuan.

\section{Desain Penelitian}

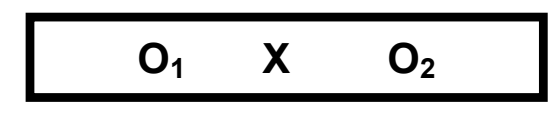

Gambar 1. Desain Penelitian Eksperimen One-Group Pretest - Posttest design

Keterangan :

$\mathrm{O}_{1}=$ Nilai Pre test ( sebelum diberi perlakuan )

$\mathrm{X}=$ Perlakuan (pembelajaran dengan menggunakan model kooperatif tipe kepala bernomor sturuktur terintegrasi nilai keislaman.

$\mathrm{O}_{2}=$ Nilai Post test ( setelah diberi perlakuan ) 
PEPATUDZU: Media Pendidikan dan Sosial Kemasyarakatan p-ISSN: 2087-3476 | e-ISSN: 2541-5700

\section{Instrumen Penelitian}

Instrumen yang digunakan pada penelitian ini adalah lembar observasi aktivitas siswa dan lembar observasi keterlaksanaan peneliti dalam pembelajaraan dan tes kemampuan pemahaman konsep matematika. Tes diberikan pada saat pretest dan posttes yang bertujuan untuk mengukur kemampuan pemahaman siswa dalam menyelesaikan relasi dan fungsi yang terintegrasi nilai-nilai Islam.

1. Lembar Observasi

Lembar Observasi aktivitas siswa dilakukan setiap kali pertemuan yaitu sebanyak 3 kali pertemuan dan lembar observasi peneliti untuk mengetahui keterlaksanaan peneliti dalam pembelajaran. Adapun tabel kategori keaktifan aktivitas siswa dapat dilihat pada tabel 1.

Tabel 1. Kategori keaktifan aktivitas siswa (Sumber : Suharsimi, 2006)

\begin{tabular}{|c|c|}
\hline Persentase & Kategori \\
\hline $90 \%<x \leq 100 \%$ & Sangat aktif \\
\hline $75 \%<x \leq 90 \%$ & Aktif \\
\hline $60 \%<x \leq 75 \%$ & Kurang aktif \\
\hline $40 \%<x \leq 60 \%$ & Tidak aktif \\
\hline $0 \%<x \leq 40 \%$ & Sangat tidak aktif \\
\hline
\end{tabular}

2. Tes Hasil Belajar

Tes hasil belajar yang diperoleh dari pretest dan posttes tersebut di analisis untuk melihat skor dan rata-rata hasil tes. Selanjutnya menghitung N-Gain antara pretest dan posttest untuk mengetahui kenaikan rata-rata hasil belajar siswa. untuk menghitung skor Gain yang dinormalisasi dapat digunakan rumus (Archambault, 2008) yaitu:

$$
N-\text { Gain }(g)=\frac{\text { Skor posttes }- \text { Skor pretest }}{\text { Skor Maksimal-Skor Pretest }} \times 100 \%
$$

Kriteria perolehan skor N-Gain dapat dilihat pada tabel 2 berikut. 
PEPATUDZU: Media Pendidikan dan Sosial Kemasyarakatan p-ISSN: 2087-3476 | e-ISSN: 2541-5700

Tabel 2. Kategori perolehan skor N-Gain

\begin{tabular}{|c|c|}
\hline Skor & Kategori \\
\hline$g>0,7$ & Tinggi \\
\hline $0,3<g \leq 0,7$ & Sedang \\
\hline$g \leq 0,3$ & Rendah \\
\hline
\end{tabular}

Adapun nilai kriteria ketuntasan minimal (KKM) di SMK Mega Link Majene kelas X seperti tabel 3 berikut.

Tabel 3. Kategori ketuntasan pemahaman konsep matematika SMK Mega Link Majene.

(Sumber: Guru Mata Pelajaran Matematika SMK Mega Link Majene)

\begin{tabular}{|c|c|}
\hline Skor & Kategori \\
\hline $0 \leq x<70$ & Tidak tuntas \\
\hline $70 \leq x \leq 100$ & Tuntas \\
\hline
\end{tabular}

Kemudian Teknik Analisis data yang digunakan adalah statistik deskriptif yang bertujuan untuk mengetahui rata-rata tes kemampuan pemahaman konsep siswa dan statistik inferensial digunakan untuk uji hipotesis sebelum dilakukan uji hipotesis maka terlebih dahulu dilakukan uji pra syarat yaitu uji normalitas.

\section{HASIL DAN PEMBAHASAN}

Data yang diperoleh dalam penelitian ini adalah data kuantitatif dan data kualitatif. Data kuantitatif diperoleh dari hasil pre-test dan post-test. Data kualitatif diperoleh dari data hasil aktivitas siswa dan keterlaksanaan peneliti dalam proses pembelajaran. Data tersebut diolah dan dianalisis guna memperoleh kesimpulan hasil penelitian.

1. Analisis Data dari Instrumen Tes kemampuan pemahaman konsep matematis siswa

Analisis statistik deskriptif pre-test dan Post test kelas X SMK Mega Link Majene 
PEPATUDZU: Media Pendidikan dan Sosial Kemasyarakatan p-ISSN: 2087-3476 | e-ISSN: 2541-5700

Berdasarkan hasil analisis data deskriptif, nilai tes pemahaman konsep Matematika siswa kelas X SMK Mega Link Majene. Hasil pre-test dan post test diuraikan pada tabel 4 berikut:

Tabel 4. Analisis statistik deskriptif pre-test dan Post test kelas X SMK Mega Link Majene (Sumber: Hasil olah data SPSS)

\begin{tabular}{|l|c|c|}
\hline Statistik deskriptif & Pre test & Post test \\
\hline Mean & 50,65 & 82,45 \\
\hline Std. Deviation & 19,79 & 13,20 \\
\hline Variance & 391,71 & 174,36 \\
\hline Maksimum & 94 & 95 \\
\hline Minimum & 19 & 50 \\
\hline
\end{tabular}

Berdasarkan data pada Tabel 4, terlihat bahwa nilai pre-test siswa kelas X diperoleh rata-rata 50,65 standar deviasi dari data nilai pre test yang dicapai siswa yaitu 19,79; variansi data tersebut adalah 391,71 ; nilai maksimum 94 dan nilai minimum 19. Sedangkan nilai post test siswa kelas $X$ diperoleh nilai rata - rata siswa 82,45 ; standar deviasi yang dihasilkan dari data nilai pemahaman konsep Matematika yang dicapai siswa kelas X SMK Mega Link Majene adalah sebesar 13,20; variansi 174,36 , nilai maksimum 95 dan minimum 50 . Nilai pre test dan post tes tersebut kemudian dihitung tingkat kenaikan hasil belajarnya untuk mengetahui efektifitas pembelajaran dengan model kepala bernomor struktur pada materi relasi dan fungsi yang terintegrasi nilai-nilai keislaman yang digunakan adalah rumus N-Gain ternormalisasi. Berdasarkan hasil perhitungan $\mathrm{N}$-Gain ternormalisasi diperoleh rata-rata kenaikan belajar dari 20 siswa adalah 0,60. Menurut (Archambault, 2008) nilai tersebut menunjukkan bahwa hasil belajar siswa berada pada kategori sedang.

Tabel 5. Deskripsi ketuntasan pemahaman konsep post-test Matematika Siswa Kelas X SMK Mega Link Majene (Sumber: SMK Mega Link Majene)

\begin{tabular}{|c|c|c|c|c|}
\hline KKM & Skor & Kategori & Frekuensi & Persentase (\%) \\
\hline \multirow{2}{*}{70} & $0 \leq x<70$ & Tidak Tuntas & 3 & 15 \\
\hline & $70 \leq x \leq 100$ & Tuntas & 17 & 85 \\
\hline \multicolumn{3}{|c|}{ Jumlah } & 20 & 100 \\
\hline
\end{tabular}

Berdasarkan tabel 5 dapat diketahui bahwa, banyaknya siswa yang tidak tuntas pada Post test sebanyak 3 siswa atau sebesar 15\% dari 20 siswa. Dan banyaknya siswa yang berada pada kategori tuntas sebanyak 17 siswa atau 
sebesar $85 \%$ dari 20 siswa. Data tersebut memperlihatkan bahwa siswa SMK kelas X SMK Mega Link Majene yang tuntas setelah diterapkan model pembelajaran kooperatif tipe kepala bernomor struktur terintegrasi nilai keislaman lebih besar dari jumlah siswa yang tidak tuntas. Ini membuktikan bahwa setelah diterapkan model pembelajaran kooperatif tipe kepala bernomor struktur terintegrasi nilai keislaman pemahaman konsep siswa mengalami peningkatan. Dengan kata lain, pembelajaran dengan menggunakan menerapkan model pembelajaran kooperatif tipe kepala bernomor struktur terintegrasi nilai keislaman berpengaruh terhadap pemahaman konsep Matematika siswa.

\section{Analisis statistik inferensial}

1. Uji Normalitas Pre test

Berdasarkan hasil uji normalitas pre test diperoleh nilai signifikansi 0,171 yang lebih besar dari 0,05 sehingga $H_{0}$ diterima dan $H_{1}$ ditolak yang berarti bahwa data skor pemahaman konsep pre test matematika siswa kelas X SMK Mega Link Majene berasal dari populasi yang berdistribusi normal.

2. Uji Normalitas post-test

Berdasarkan hasil uji normalitas post test diperoleh nilai signifikansi 0,147 yang lebih besar dari 0,05 sehingga $H_{0}$ diterima dan $H_{1}$ ditolak yang berarti bahwa data skor pemahaman konsep Post test matematika siswa kelas X SMK Mega Link Majene berasal dari populasi yang berdistribusi normal.

\section{Uji Hipotesis}

Pengujian pemahaman konsep posttes siswa dengan One-sample t test.

Rumusan hipotesis dalam bentuk kalimat adalah :

$\mathbf{H}_{\mathrm{o}}=$ Model pembelajaran kooperatif tipe kepala bernomor struktur terintegrasi nilai keislaman tidak berpengaruh terhadap pemahaman konsep Matematika siswa kelas X SMK Mega Link Majene

$\mathbf{H}_{1}=$ Model pembelajaran kooperatif tipe kepala bernomor struktur terintegrasi nilai keislaman berpengaruh terhadap pemahaman konsep Matematika siswa kelas X SMK Mega Link Majene

One-Sample Test

\begin{tabular}{|c|c|c|c|c|c|c|}
\hline & \multicolumn{6}{|c|}{ Test Value $=70$} \\
\hline & \multirow[b]{2}{*}{$\mathrm{t}$} & \multirow[b]{2}{*}{ df } & \multirow{2}{*}{$\begin{array}{l}\text { Sig. }(2- \\
\text { tailed) }\end{array}$} & \multirow{2}{*}{$\begin{array}{c}\text { Mean } \\
\text { Difference }\end{array}$} & \multicolumn{2}{|c|}{$\begin{array}{l}95 \% \text { Confidence } \\
\text { Interval of the } \\
\text { Difference }\end{array}$} \\
\hline & & & & & Lower & Upper \\
\hline Posttest & 4.217 & 19 & .000 & 12.450 & 6.27 & 18.63 \\
\hline
\end{tabular}


Uji hipotesis One-Sample T-Test post-test siswa kelas X diperoleh nilai signifikasi 0,000 . oleh karena signifikasi $0,00<0,05$. Maka dapat disimpulkan bahwa $\mathrm{H}_{0}$ ditolak dan $\mathrm{H}_{1}$ diterima. Hal ini berarti bahwa Model pembelajaran kooperatif tipe kepala bernomor struktur terintegrasi nilai keislaman efektif terhadap pemahaman konsep Matematika siswa kelas X SMK Mega Link Majene

\section{Analisis Data dari Instrumen Non Tes}

1. Hasil Observasi Aktivitas Siswa

Data hasil observasi aktivitas siswa selama proses pembelajaran dilaksanakan dinalisis dan di deskripsikan. Pengisian lembar observasi dilakukan pada saat pembelajaran berlangsung. Pembelajaran dilakukan sebanyak 3 kali pertemuan.

Hasil observasi siswa kelas $\mathrm{X}$ menunjukkan bahwa pada pertemuan pertama persentase aktivitas siswa $85 \%$, pada pertemuan kedua persentase aktivitas siswa $100 \%$, pada pertemuan ketiga $100 \%$ dan Sehingga nilai rata-rata hasil observasi aktivitas siswa adalah $95 \%$.

Berdasarkan tabel 1 kategori keaktifan aktivitas siswa, maka aktivitas siswa berada pada kategori sangat aktif dengan nilai rata-rata hasil observasi aktivitas siswa adalah $95 \%$.

2. Hasil Observasi Keterlaksanaan Peneliti dalam Proses Pembelajaran

Hasil observasi keterlaksanaan peneliti dalam pembelajaran diuraikan pada tabel 6 berikut.

Tabel 6. Keterlaksanaan peneliti dalam proses pembelajaran

\begin{tabular}{|c|c|c|c|c|c|c|c|c|}
\hline \multirow{2}{*}{ Aspek yang diobservasi } & \multicolumn{3}{|c|}{ Pertemuan } & \multirow{2}{*}{ Rata- } & $\begin{array}{c}\text { Persen } \\
\text { tase } \\
\text { rata }\end{array}$ & Kriteria \\
\cline { 2 - 5 } A. PENDAHULUAN & 1 & 2 & 3 & 1 & 100 & Terpenuhi \\
\hline $1 . \quad \begin{array}{l}\text { Membuka } \\
\text { pelajaran dengan } \\
\text { salam dan } \\
\text { menanyakan } \\
\text { kehadiran siswa }\end{array}$ & 1 & 1 & 1 & 1 & 100 & Terpenuhi \\
\hline $\begin{array}{l}\text { membimbing } \\
\text { siswa untuk } \\
\text { mempersiapkan } \\
\text { diri mengikuti } \\
\text { kegiatan } \\
\text { pebelajaran }\end{array}$ & 1 & 1 & 1 & 1 & & \\
\hline
\end{tabular}


PEPATUDZU: Media Pendidikan dan Sosial Kemasyarakatan

Vol. 15, No. 2, November 2019 p-ISSN: 2087-3476 | e-ISSN: 2541-5700

\begin{tabular}{|c|c|c|c|c|c|c|c|}
\hline \multirow{2}{*}{\multicolumn{2}{|c|}{ Aspek yang diobservasi }} & \multicolumn{3}{|c|}{ Pertemuan } & \multirow{2}{*}{$\begin{array}{c}\text { Rata- } \\
\text { rata }\end{array}$} & \multirow{2}{*}{$\begin{array}{l}\text { Persen } \\
\text { tase } \\
(\%)\end{array}$} & \multirow[t]{2}{*}{ Kriteria } \\
\hline & & \multirow[t]{2}{*}{1} & \multirow[t]{2}{*}{2} & \multirow[t]{2}{*}{3} & & & \\
\hline & $\begin{array}{l}\text { dengan berdoa } \\
\text { terlebih dahulu, } \\
\text { kemudian } \\
\text { membaca } \\
\text { beberapa surah } \\
\text { pendek. }\end{array}$ & & & & & & \\
\hline 3. & $\begin{array}{l}\text { menyampaikan } \\
\text { strategi } \\
\text { pembelajaran } \\
\text { yang digunakan }\end{array}$ & 1 & 1 & 1 & 1 & 100 & Terpenuhi \\
\hline 4. & $\begin{array}{l}\text { Menyampaikan } \\
\text { tujuan } \\
\text { pembelajaran }\end{array}$ & 1 & 1 & 1 & 1 & 100 & Terpenuhi \\
\hline 5 . & $\begin{array}{l}\text { Peneliti } \\
\text { melakukan } \\
\text { apersepsi dengan } \\
\text { Mengingatkan } \\
\text { kembali materi } \\
\text { yang telah } \\
\text { dipelajari } \\
\text { sebelumnya } \\
\text { terkait } \\
\text { pembelajaran } \\
\text { pertemuan hari } \\
\text { ini. }\end{array}$ & 1 & 1 & 1 & 1 & 100 & Terpenuhi \\
\hline 6. & $\begin{array}{l}\text { Memberikan } \\
\text { motivasi pada } \\
\text { siswa. }\end{array}$ & 1 & 1 & 1 & 1 & 100 & Terpenuhi \\
\hline & $\begin{array}{l}\text { Aspek Pada Kegiat } \\
\text { TI }\end{array}$ & $n \mathrm{P}$ & ada & ulu & & 100 & Terpenuhi \\
\hline & $\begin{array}{l}\text { Membentuk } \\
\text { kelompok belajar } \\
\text { yang terdiri dari } 4 \\
\text { orang siswa. }\end{array}$ & 1 & 1 & 1 & 1 & 100 & Terpenuhi \\
\hline
\end{tabular}


PEPATUDZU: Media Pendidikan dan Sosial Kemasyarakatan

Vol. 15, No. 2, November 2019 p-ISSN: 2087-3476 | e-ISSN: 2541-5700

\begin{tabular}{|c|c|c|c|c|c|c|}
\hline \multirow[b]{2}{*}{ Aspek yang diobservasi } & \multicolumn{3}{|c|}{ Pertemuan } & \multirow{2}{*}{$\begin{array}{c}\text { Rata- } \\
\text { rata }\end{array}$} & \multirow{2}{*}{$\begin{array}{l}\text { Persen } \\
\text { tase } \\
(\%)\end{array}$} & \multirow[t]{2}{*}{ Kriteria } \\
\hline & 1 & 2 & 3 & & & \\
\hline $\begin{array}{ll}\text { 2. } & \text { Membagikan } \\
\text { Bahan Ajar relasi } \\
\text { dan fungsi yang } \\
\text { terintegrasi nilai- } \\
\text { nilai keislaman } \\
\text { kepada setiap } \\
\text { kelompok. }\end{array}$ & 1 & 1 & 1 & 1 & 100 & Terpenuhi \\
\hline $\begin{array}{ll}\text { 3. } & \text { Menyampaikan } \\
& \text { tentang pokok } \\
& \text { materi } \\
& \text { pembelajaran } \\
\end{array}$ & 1 & 1 & 1 & 1 & 100 & Terpenuhi \\
\hline $\begin{array}{ll}4 . & \text { Mengarahkan } \\
\text { siswa membaca } \\
\text { dan memahami } \\
\text { soal yang ada pada } \\
\text { Bahan Ajar } \\
\end{array}$ & 1 & 1 & 1 & 1 & 100 & Terpenuhi \\
\hline $\begin{array}{ll}5 . & \text { Meminta siswa } \\
\text { Menanyakan hal- } \\
\text { hal yang belum } \\
\text { dipahami. }\end{array}$ & 1 & 1 & 1 & 1 & 100 & Terpenuhi \\
\hline $\begin{array}{ll}\text { 6. } & \text { Membagikan } \\
& \text { Lembar Kerja } \\
\text { Kelompok (LKK) } & \text { berupa Tugas } \\
\text { Kelompok. }\end{array}$ & 1 & 1 & 1 & 1 & 100 & Terpenuhi \\
\hline $\begin{array}{ll}\text { 7. } & \text { Mengarahkan } \\
\text { siswa membaca } \\
\text { referensi lain dan } \\
\text { membandingkan } \\
\text { dengan hasil } \\
\text { diskusi. }\end{array}$ & 0 & 1 & 1 & 0,667 & 66,67 & $\begin{array}{c}\text { Tidak } \\
\text { terpenuhi }\end{array}$ \\
\hline $\begin{array}{ll}\text { 8. } & \text { Berkeliling } \\
& \text { membimbing } \\
& \text { kelompok. }\end{array}$ & 1 & 1 & 1 & 1 & 100 & Terpenuhi \\
\hline
\end{tabular}


PEPATUDZU: Media Pendidikan dan Sosial Kemasyarakatan

Vol. 15, No. 2, November 2019 p-ISSN: 2087-3476 | e-ISSN: 2541-5700

\begin{tabular}{|c|c|c|c|c|c|c|c|}
\hline \multirow{2}{*}{\multicolumn{2}{|c|}{ Aspek yang diobservasi }} & \multicolumn{3}{|c|}{ Pertemuan } & \multirow{2}{*}{$\begin{array}{l}\text { Rata- } \\
\text { rata }\end{array}$} & \multirow{2}{*}{$\begin{array}{l}\text { Persen } \\
\text { tase } \\
(\%)\end{array}$} & \multirow[t]{2}{*}{ Kriteria } \\
\hline & & 1 & 2 & 3 & & & \\
\hline & $\begin{array}{l}\text { Setelah selesai, } \\
\text { peneliti } \\
\text { membagikan } \\
\text { nomor struktur } \\
\text { kepala kepada } \\
\text { masing-masing } \\
\text { kelompok dengan } \\
\text { nomor siswa yang } \\
\text { berbeda dalam } \\
\text { satu kelompok. }\end{array}$ & 1 & 1 & 1 & 1 & 100 & Terpenuhi \\
\hline & $\begin{array}{l}\text { Menyampaikan } \\
\text { aturan main } \\
\text { kepala bernomor } \\
\text { struktur. }\end{array}$ & 1 & 1 & 1 & 1 & 100 & Terpenuhi \\
\hline & $\begin{array}{l}\text { Siswa } \\
\text { mengerjakan tugas } \\
\text { yang diberikan } \\
\text { sesuai nomor } \\
\text { struktur } \\
\text { kepalanya } \\
\end{array}$ & 1 & 1 & 1 & 1 & 100 & Terpenuhi \\
\hline 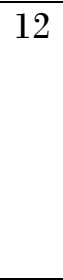 & $\begin{array}{l}\text { Setelah selesai, } \\
\text { Siswa diarahkan } \\
\text { untuk bergabung } \\
\text { dengan nomor } \\
\text { struktur kepala } \\
\text { yang sama. }\end{array}$ & 1 & 1 & 1 & 1 & 100 & Terpenuhi \\
\hline 13 & $\begin{array}{l}\text { Setelah selesai } \\
\text { berdiskusi dengan } \\
\text { nomor struktur } \\
\text { dan tugas yang } \\
\text { sama, siswa } \\
\text { diarahkan kembali } \\
\text { ke kelompok } \\
\text { masing-masing } \\
\text { dan menuliskan } \\
\text { hasil diskusi pada } \\
\text { lembar jawaban. }\end{array}$ & 1 & 1 & 1 & 1 & 100 & Terpenuhi \\
\hline
\end{tabular}


PEPATUDZU: Media Pendidikan dan Sosial Kemasyarakatan

Vol. 15, No. 2, November 2019 p-ISSN: 2087-3476 | e-ISSN: 2541-5700

\begin{tabular}{|c|c|c|c|c|c|c|}
\hline \multirow{2}{*}{ Aspek yang diobservasi } & \multicolumn{3}{|c|}{ Pertemuan } & \multirow{2}{*}{$\begin{array}{l}\text { Rata- } \\
\text { rata }\end{array}$} & \multirow{2}{*}{$\begin{array}{c}\text { Persen } \\
\text { tase } \\
(\%)\end{array}$} & \multirow[t]{2}{*}{ Kriteria } \\
\hline & 1 & 2 & 3 & & & \\
\hline $\begin{array}{ll}14 & \text { Menyuruh setiap } \\
& \text { kelompok } \\
& \text { menujukkan } \\
\text { perwakilan untuk } \\
\text { mempersentasikan } \\
\text { hasil diskusi tugas } \\
\text { kelompok yang } \\
\text { diberikan. }\end{array}$ & 1 & 1 & 1 & 1 & 100 & Terpenuhi \\
\hline $\begin{array}{ll}15 & \text { Meminta } \\
& \text { kelompok lain } \\
& \text { untuk menyimak } \\
& \text { dan membeikan } \\
& \text { tanggapan } \\
& \text { terhadap hasil } \\
& \text { presentasi teman - } \\
\text { temannya. }\end{array}$ & 1 & 1 & 1 & 1 & 100 & Terpenuhi \\
\hline $\begin{array}{ll}16 & \text { Memberikan } \\
& \text { penguatan } \\
& \text { terhadap hasil } \\
& \text { presentasi siswa. }\end{array}$ & 1 & 1 & 1 & 1 & 100 & Terpenuhi \\
\hline \multicolumn{7}{|c|}{ Aspek Pada Kegiatan Inti } \\
\hline $\begin{array}{ll}\text { 1. } & \text { Peneliti } \\
\text { membimbing } \\
\text { merangkum dan } \\
\text { merefleksi materi } \\
\text { yang telah } \\
\text { dipelajari. }\end{array}$ & 1 & 1 & 1 & 1 & 100 & Terpenuhi \\
\hline $\begin{array}{l}\text { 2. Memberi } \\
\text { penghargaan bagi } \\
\text { kelompok yang } \\
\text { aktif. } \\
\end{array}$ & 1 & 1 & 1 & 1 & 100 & Terpenuhi \\
\hline $\begin{array}{ll}\text { 3. } & \text { Menginformasikan } \\
\text { tentang materi }\end{array}$ & 1 & 1 & 1 & 1 & 100 & Terpenuhi \\
\hline
\end{tabular}


PEPATUDZU: Media Pendidikan dan Sosial Kemasyarakatan p-ISSN: 2087-3476 | e-ISSN: 2541-5700

\begin{tabular}{|c|c|c|c|c|c|c|}
\hline \multirow{2}{*}{ Aspek yang diobservasi } & \multicolumn{3}{|c|}{ Pertemuan } & Rata- & $\begin{array}{c}\text { Persen } \\
\text { tase } \\
(\%)\end{array}$ & \\
\cline { 2 - 6 } & 1 & 2 & 3 & rata & & \\
\hline selanjutnya. & & & & & & \\
\hline \multicolumn{2}{|c|}{ Aspek Pada Kegiatan Penutup } & 100 & Terpenuhi \\
\hline
\end{tabular}

Berdasarkan tabel diatas, keterlaksanaan peneliti dalam proses pembelajaran terlihat bahwa terdapat satu aspek dari kegiatan inti yang berada pada kategori tidak terpenuhi sedangkan untuk setiap aspek pada kegiatan Pendahuluan dan Penutup berada pada kategori terpenuhi.

\section{SIMPULAN}

Berdasarkan hasil tes pemahaman konsep siswa pada materi relasi dan fungsi yang terintegrasi nilai-nilai keislaman diperoleh ketuntasan klasikal mencapai $85 \%$, aktivitas belajar siswa berada pada kategori sangat aktif yaitu 95\% dan keterlaksanaan peneliti dalam proses pembelajaran berada pada kategori terpenuhi serta hasil hitung $\mathrm{N}$-Gain diperoleh rata-rata kenaikan hasil belajar 0,60 , uji analisis one sampel t test diperoleh signifikansi $0,00<0,05$, maka dapat disimpulkan bahwa penerapan model pembelajaran kepala bernomor struktur pada materi relasi dan fungsi terintegrasi nilai keislaman berpengaruh terhadap pemahaman konsep Matematis siswa.

\section{SARAN}

Berdasarkan hasil penelitian bahwa penerapan model pembelajaran kepala bernomor struktur pada materi relasi dan fungsi yang terintegrasi nilai keislaman berpengaruh terhadap pemahaman konsep Matematis siswa maka disarankan untuk menggunakan model kepala bernomor struktur untuk materi lain pada pembelajaran matematika dengan mengintegrasikan nilai-nilai keislaman.

\section{DAFTAR PUSTAKA}

Abdussakir, dan Rosimanidar. 2017. Model Integrasi Matematika dan Alquran serta Praktik Pembelajarannya. Disajikan dalam seminar nasional integrasi matematika di dalam Alquran (pp.1-16). Bukit tinggi: Jurusan Matematika. 
Abdussakir. 2018. Integrating Mathematics and Religious Teachings and Values in Elementary and Secondary School, Keynote Speaker Full Paper dalam International Conference on Mathematics and Islam pada tanggal $3-5$ Agustus 2018 di Mataram Nusa Tenggara Barat.

Archambault, J., Burch, T., Crofton, M., \& McClure, A. (2008). The effect of developing kinematics concepts graphically prior to introducing algebraic problem solving techniques. Action Research required for the Master of Natural Science degree with concentration in physics.

Arifin, N. N., Nura'eni, E., \& Pranata, O. H. (2014). Peningkatan pemahaman siswa terhadap materi geometri melalui pembelajaran berbasis teori Van Hiele. PEDADIDAKTIKA: Jurnal Ilmiah Pendidikan Guru Sekolah Dasar, 1(2), 96-102.

Herawati, O. D. P., Siroj, R. A., \& Basir, M. D. (2010). Pengaruh pembelajaran problem posing terhadap kemampuan pemahaman konsep matematika siswa kelas xi ipa sma negeri 6 palembang. Jurnal Pendidikan Matematika, $4(1), 70-80$.

Isjoni. 2007. Cooperative Learning Efektifitas Pembelajaran Kelompok. Bandung: Alfabeta

Kesumawati, N. (2008). Pemahaman Konsep Matematik dalam Pembelajaran Matematika. Semnas Matematika dan Pendidikan Matematika, 2, 231-234.

Nasional, D. P. (2010). Model-model Pembelajaran yang Efektif. Tersedia: http://ktsp. diknas, go. id/download/ktsp-smp/14 ppt.

Nasir, M., Dollo, A., \& Buhaerah, B. 2017. Model Pembelajaran Model Pembelajaran Berpikir Kritis yang Terintegrasi Nilai-nilai Islami. In Prosiding SI Manis (Seminar Nasional Integrasi Matematika dan NilaiNilai Islami) (Vol.1,No.1,pp.141-146).

National Council of Teachers of Mathematics. 2000. Principles and Standars for School Mathematics. Reston, VA: NCTM.

Sari, D. P. (2018). Pengaruh Model Pembelajaran Tipe Numbered Heads Together terhadap Kemampuan Pemahaman Konsep Matematika. Jurnal Mathematic Paedagogic, 2(2), 196-203.

Sugiono. 2016. Metode Penelitian Kuantitatif, Kualitatif, dan R\&D. Bandung : Alfabeta

Suharsimi, A. (2006). Prosedur penelitian suatu pendekatan praktik. Jakarta: Rineka Cipta.

Suprijono, Agus. 2013. Cooperative Learning (Teori dan Aplikasi Paikem). Jogjakarta: Pustaka Pelajar. 